ZBIGNIEW MAREK SJ, Biblia $w$ katechetycznej postudze stowa, Biblioteka Horyzontów Wiary, Kraków 1998, ss. 232.

Jest to bardzo interesująca pozycja $\mathrm{z}$ punktu widzenia popularyzacji słowa Bożego wśród wiernych. Przybliża ona w prosty i przystępny sposób zasady i metody pracy z tekstami biblijnymi, które można wykorzystać zarówno w katechizacji, jak i w ramach działalności grup o charakterze formacyjnym.

Książkę tę można by podzielić na dwie tematyczne części: teoretyczną i praktyczną. Pierwsza zawiera omówienie katechetycznej posługi słowa: natura, charakterystyka, cele i zadania, treść oraz znaczenie Biblii w tej dziedzinie. Druga część to część praktyczna, zawierająca metody pracy z tekstami Pisma Swiętego. Na uwagę zasługują tutaj zwłaszcza metody wciągające słuchaczy w sposób czynny do odkrywania biblijnych treści, jak przedstawienie sceniczne, praca $z$ obrazami, rysunkami i schematami oraz formami muzycznymi. Bardzo urozmaicają one przekaz, wprowadzają element zaciekawienia, a także pomagają w zapamiętaniu.

Praca ta, służąca jako pomoc w odkrywaniu biblijnego orędzia o zbawieniu, jest godna polecenia przede wszystkim dla duszpasterzy, katechetów, studentów teologii oraz moderatorów grup biblijnych i formacyjnych.

Węgrzce $k$ / Krakowa

Ks. GRZEGORZ ŁOPATKA

\title{
PRZEGLĄD BIBLIOGRAFICZNY
}

\section{COLLECTANAE THEOLOGICA}

1995 z. 3

B i e l e c k i St., ks., Kairos chrześcijanina wedtug Rz 13, 11-14; 85-99.

1995 z. 4

K i e j z a A., OFMCap, Charakter obecności Chrystusa $w$ Kościele wedtug Ap 1, 12-20; 21-38; L e w a n d o w i c z G., Biblizmy we wspótczesnym języku polskim, 5-20.

1996 z. 1

$\mathrm{C} \mathrm{h} \mathrm{r} \mathrm{o} \mathrm{s} \mathrm{t} \mathrm{o} \mathrm{w} \mathrm{s} \mathrm{k} \mathrm{i} \mathrm{W.,} \mathrm{ks.,} \mathrm{Żydowskie} \mathrm{tradycje} \mathrm{interpretacyjne} \mathrm{pomoca}$ $w$ zrozumieniu Biblii, 39-54; D ą b e k T, OSB, Sensy Pisma świętego $w$ świetle dokumentu „Interpretacja Biblii $w$ Kościele”, 84-104; $\mathrm{H}$ a $\nmid$ a s St., SCJ, Analiza struktury literackiej droga do lepszego rozumienia tekstu biblijnego, 25-38; J e z i e r s k a E.J., OSU, Feministyczne podejście $w$ interpretacji Biblii, 65-74; K r a i ń s k i J., ks., Ks. prof. Jan Stepień (1910-1995). Biblista i rektor ATK, 169-182; R u b i n k i e w i c z R., SDB, Nowe aspekty egzegezy biblijnej w świetle doḳumentu Papieskiej Komisji Biblijnej o „Interpretacji Biblii w Kościele”, 9-24; S u c h y J., Podejście psychologicz- 